\author{
黒木 祥文 $^{1}$
}

\begin{abstract}
超純水装置の高性能化と普及により極微量分析に要求される超純水は容易に得られるようになった。しか しその利用に際しては適切な装置の選定, 管理, 使用法が求められる. 実際に超純水が分析目的に応じた水 質を維持できているかをモニタリングすることは容易ではない. 特に極微量元素分析やホウ素, シリカの分 析には超純水の水質低下に比抵抗計だけではモニタリングできないことを認識する必要がある．また超純水 は様々な要因で污染される. 主な污染例のひとつとして分析装置あるいは超純水装置そのものが要因となる ものがある. 環境からの污染も多く雾囲気や容器などからの污染によるものがある. 容器に付着した污れが 超純水に溶解して生じるだけでなく容器そのものが超純水に溶け出すので容器の選択には注意が必要であ る. また分析の操作中に人から污染するものがある. 多くの事例では超純水の性格を理解していれば防止で きていたものが多い，超純水の理解と適切な取り扱いは微量分析の感度, 精度そして信頼性の向上につなが る.
\end{abstract}

\section{1 はじめに}

分析において「水」は最も頻繁にそして大量に使われる 試薬であり溶媒である。そその水質は当然分析に大きな影響 を与える.そのため一般に分析には何らかの精製処理を施 し分析阻害物質を除去した水を用いる。 その呼び名は様々 で，処理したことやその方法を示した「精製水」、「蒸留 水」,「イオン交換水」「RO (逆浸透膜) 処理水」であった り，目的物を除去あるいは不活化したことを示した「滅菌 水」「RNase (RNA 分解酵素) フリー水」などであったり, 単純にきれいで混ざり気がないという意味を表した「純 水」「超純水」と呼ばれたりする. 実際にこれらの呼称は論 文にも用いられており，また市販されている水の製品名に も使用されている.しかしこれらの呼称は水質を規定した ものではないため, Table 1 で示すように残存有機物を比 較しても非常にばらつきがある.またあくまでも Table 1 に挙げた水質は処理開始時の到達值であり実際の使用時に は供給水の水質変動や処理量の増加により水質低下が起こ り得る. 現在も，使用した分析用水の水質が規定されるか 明確になるようには論文への記載方法が統一なされていな いことなど，分析の再現性を確保するために指摘，改善す べき点は多( ${ }^{12)}$. しかしどのような呼称を用いるにせよ， 高度の精製を施し, 分析に影響を与える不純物を十分に除 去した水は微量分析に不可欠である。高純度の純水を容易 にかつ大量に研究室内で使用時に製造できるラボ用「超純

ヴェオリア・ウォーター・ソリューション\&テクノロジー株式 会社エルガ・ラボウォーター事業部 : 108-0022 東京都港区海 岸 3-20-20 ヨコソーレインボータワー
水装置」の普及と高性能化は微量分析に大きく寄与してき た. 水質への理解は不十分であるにせよ少なくとも微量分 析を行う際に「超純水」を用いることは分析者のコンセン サスを得られていると思われる。

著者は長らく超純水装置の研究, 開発に携わるなかで, 多くの分析者から超純水装置や超純水の使用例と微量分析 に関する数多くの知見，助言を得ることが出来た．近年は 供給される超純水の供給水質が問題ではなくその周辺に存 在する様々な要因により生じた污染が微量分析を阻害する 事例を散見する，本稿ではそれらの超純水にかかわる事例 をもとに微量分析の精度に影響を与える污染要因とその対

Table 1 TOC of purified water

\begin{tabular}{llc}
\hline $\begin{array}{c}\text { Water category/ } \\
\text { Water quality } \\
\text { standard }\end{array}$ & \multicolumn{1}{c}{ Water name } & $\begin{array}{c}\text { Total organic } \\
\text { carbon/ } \\
\mathrm{mgC} \mathrm{L}^{-1}\end{array}$ \\
\hline Raw Water & Tap Water/Industrial Water & $1 \sim 3$ \\
Pure Water & Distilled Water & $0.05 \sim 0.3$ \\
& Ion Exchange (IE) Water & $0.01 \sim 0.5$ \\
& Reverse Osmosis (RO) Water & $0.02 \sim 0.3$ \\
& RNase Free Water & $0.05 \sim 100$ \\
Ultra-pure & Ultra-pure Water & $0.01 \sim 0.05$ \\
Water & (RO + IE + Activated Carbon) & \\
& Ultra-pure Water & \\
& (RO + IE + Activated Carbon + UV) & $0.001 \sim 0.01$ \\
\hline Drinking Water & Drinking Water/Tap Water & $<3$ \\
Standard & A4 Grade Water & $<0.05$ \\
JIS K 0557 & (for trace material analysis) & \\
\hline
\end{tabular}


Table 2 Elements of purification technologies and impurities

\begin{tabular}{|c|c|c|c|c|}
\hline \multirow{2}{*}{ Purification in laboratories } & \multicolumn{4}{|c|}{ Impurities } \\
\hline & Inorganic matter & Organic material & Bacteria & Particle \\
\hline Ion Exchange Resin (IE or DI) & (a) & $\triangle$ & - & - \\
\hline Activated Carbon (AC) & - & 0 & - & - \\
\hline Micro Filtration Membrane (MF) & - & - & () & (a) \\
\hline Ultra Filtration Membrane (UF) & - & $\triangle$ & $\bigcirc$ & $\bigcirc$ \\
\hline Reverse Osmosis Membrane (RO) & $\triangle$ & $\triangle$ & $\bigcirc$ & $\bigcirc$ \\
\hline Distillation (DW) & $\triangle$ & $\triangle$ & $\bigcirc$ & $\bigcirc$ \\
\hline $\begin{array}{l}\text { UV irradiation (UV) } \\
\text { wavelength ; } 185 \mathrm{~nm} \text { (185UV; Oxidization) } \\
\text { wavelength ; } 254 \mathrm{~nm} \text { (254UV; Stylization) }\end{array}$ & - & $\underset{ }{0}$ & $\begin{array}{l}\bigcirc \\
\bigcirc\end{array}$ & - \\
\hline
\end{tabular}

Table 3 Trace element analysis of water from ultrapure water system

\begin{tabular}{cc}
\hline Element & Value $/ \mathrm{ng} \mathrm{L}^{-1}$ \\
\hline $\mathrm{Al}$ & 2.9 \\
$\mathrm{Sb}$ & 3.2 \\
$\mathrm{As}$ & 4.7 \\
$\mathrm{Ba}$ & $<2.3$ \\
$\mathrm{Be}$ & 0.04 \\
$\mathrm{Bi}$ & $<0.6$ \\
$\mathrm{Cd}$ & 0.16 \\
$\mathrm{Cr}$ & 2.0 \\
$\mathrm{Co}$ & 2.0 \\
$\mathrm{Cu}$ & 4.0 \\
$\mathrm{Ir}$ & 0.002 \\
$\mathrm{Fe}$ & 2.3 \\
$\mathrm{~Pb}$ & 0.7 \\
$\mathrm{Mn}$ & 1.1 \\
$\mathrm{Hg}$ & 1.3 \\
$\mathrm{Mo}$ & 2.0 \\
$\mathrm{Ni}$ & 4.2 \\
$\mathrm{Pt}$ & 0.001 \\
$\mathrm{Se}$ & 1.0 \\
$\mathrm{Ag}$ & 0.18 \\
$\mathrm{U}$ & 0.005 \\
$\mathrm{~V}$ & 0.25 \\
$\mathrm{Zn}$ & 2.2 \\
\hline
\end{tabular}

策を紹介する。

\section{2 超純水の水質が微量分析に与える影響}

純水化技術においてそれぞれ用いられる対象物質（除去 が期待できる物質）は Table 2 に示すように限定的であり, いくつかの要素を組み合わせることで超純水は精製され る. 研究室に設置された超純水装置から得られる超純水も 市販のボトル入り超純水も, 一般に工業用水や水道水を一 次処理した蒸留水, $\mathrm{RO}$ 水などを原水とし, 活性炭, イオ ン交換樹脂及びフィルターの組み合わせによって精製され $る^{1)}$. 当然用いる要素技術により得られる水の水質や管理 留意事項は異なる ${ }^{2)}$.

まず純水, 超純水の水質そのものが微量分析に与える影 響について紹介する.

\section{$2 \cdot 1$ 微量分析用超純水の水質}

元来超純水に採用されているイオン交換樹脂のイオン除 去能力は高く, 残存イオン濃度は ppt レベルを早くから達 成し ${ }^{3)}$ ，極微量元素分析用水として問題なく用いられてい $ろ^{4) \sim 6)}$. 実際に高性能のイオン交換樹脂を用いた超純水装 置から得られた超純水の残存イオン濃度の分析例を Table 3 に示す.すべてのイオンが pptレベルであること が分かる.

また液体クロマトグラフィー質量分析（LC/MS）などを 用いた微量有機物分析には超純水の精製工程に紫外線 (UV) ランプを採用した機種が開発されている7). UV 照射 による超純水中の残存有機物の低減効果は高く，現在では 微量分析用として開発された超純水装置のほぼすべての機 種に導入されている。 この技術の導入によりそれまでは長 時間の沸騰や複数回の蒸留操作など時間と労力を要して製 造していた微量有機物分析用水を容易にかつ大量に製造, 使用することが可能になった. 既に環境ホルモン, ダイオ キシン, パーフルオロオクタンスルホン酸 (PFOS), パー フルオロオクタン酸（PFOA）など微量有機物分析に問題 なく用いられている ${ }^{8) \sim 11)}$

実際に残留農薬分析を行うに際して超純水システムから 得られた水と市販ボトル水 (LC/MS 用超純水) の比較をし た例 ${ }^{12)}$ を Fig. 1 に示す.

クロマトグラムは上から順に $185 \mathrm{~nm} \mathrm{UV}$ 装着超純水装 置 PURELAB Ultra Analytic (ELGA LabWater 製) から採取 した水 $\mathrm{A}$, 同じく $185 \mathrm{~nm} \mathrm{UV}$ 装着の他社超純水装置から採 取した水 B, そして市販 LC/MS 用超純水 (ボトル水) C. すべて供給メーカーが微量有機物分析用に推奨している超 純水を用いた.

C18 カラムを用いサンプルインジェクション無しで移動

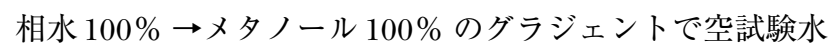
のUV $210 \mathrm{~nm}$ の吸収を比較した. 特に水による有意差は認 められない.

多くの分析事例からも現在, 微量分析用途に指定されて いる超純水の水質は微量分析に十分な水質を有していると 
いえるであろう。

\section{$2 \cdot 2$ UV 照射による超純水中の有機物低減効果}

超純水中の残存有機物の低減は $185 \mathrm{~nm} の$ 短波長紫外線 を照射して有機物を酸化分解することで達成される，供給 水中に有機体炭素 (TOC) としておよそ $100 \mu \mathrm{gC} \mathrm{L}^{-1}$ 程度 残存している有機物を, UVが無い超純水装置ではイオン 交換樹脂や活性炭の働きにより TOCを $20 \sim 30 \mu \mathrm{gC} \mathrm{L}^{-1}$ 程 度にまで低減するのに対し，Fig. 2 に示すように $185 \mathrm{~nm}$ $\mathrm{UV}$ を照射することで更に $5 \mu \mathrm{gC} \mathrm{L} \mathrm{L}^{-1}$ 未満まで低減するこ とができる ${ }^{12)}$. 更に供給水を TOC $50 \mu \mathrm{gC} \mathrm{L}^{-1}$ 以下に限定 し, UV 波長 $185 \mathrm{~nm}$ を照射する紫外線ランプが装着されて いる超純水装置を適切に管理することによって TOCを $1 \mu \mathrm{gC} \mathrm{L}{ }^{-1}$ まで低減することができる（Table 4).
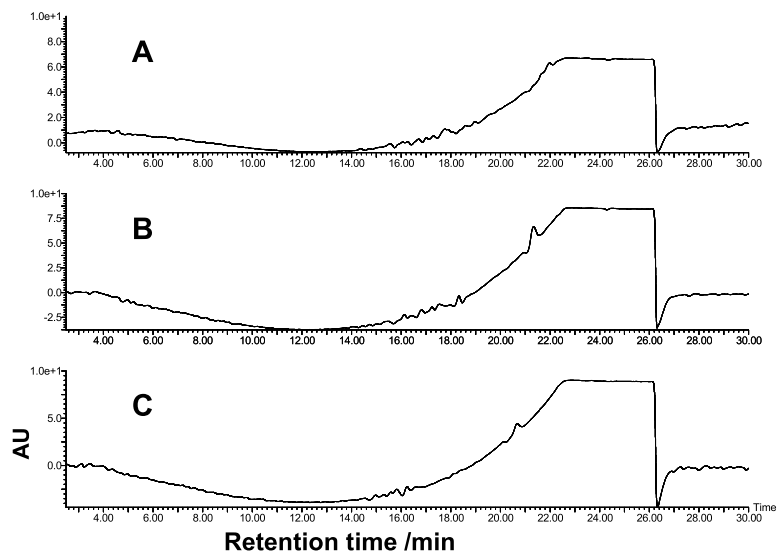

Fig. 1 Comparison of HPLC background peak ${ }^{12)}$

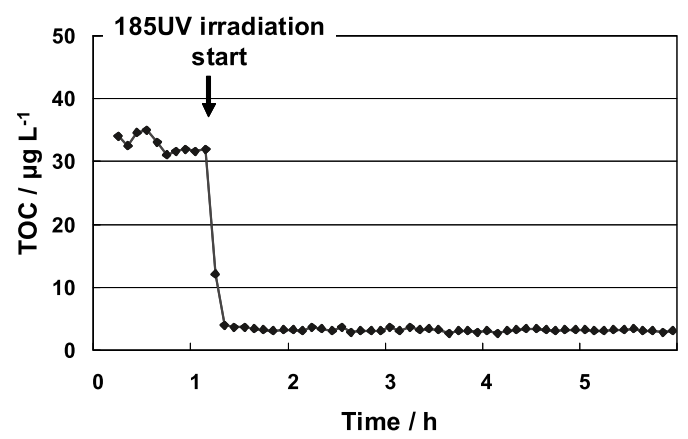

Fig. 2 Effect of organic matters reduction by 185 nmUV oxidation ${ }^{12) 13)}$
$2 \cdot 3$ 純水, 超純水中の残存有機物が分析に与える影響

TOC 值が高速液体クロマトグラフィー（HPLC）分析に おいてどのような影響を与えるかを示す.

Fig. 3 は C30 カラムを用い, サンプルインジェクション 無しの空試験として移動相だけを水 $100 \%$ からアセトニトリ ル 100\%へのグラジェントを行い, UV $210 \mathrm{~nm}$ の吸収を測定 した結果である。「Ultra-pure Water ; TOC $\left.1 \mu \mathrm{g} \mathrm{L}^{-1}\right\rfloor$ は超 純水装置 PURELAB Ultra Analytic（ELGA LabWater 製）に 搭載されている水質モニターで TOC 1 ppb の指示值を確 認した後に採水したものを用いた.「Pure Water ; TOC 50 $\left.\mu \mathrm{g} \mathrm{L}^{-1}\right\rfloor$ は純水装置 PURELAB Option-R（ELGA LabWater 製) で TOC が $50 \mu \mathrm{gC} \mathrm{L}^{-1}$ まで低減した水を用いた。この 水からは TOCが $1 \mu \mathrm{gC} \mathrm{L}^{-1}$ まで低減された超純水では全く 見られないピークが検出されている. 水中の残存有機物は 明らかにHPLC分析におけるバックグラウンドに影響を与 えている ${ }^{12)}$ ，そのクロマトグラフ上の影響の差異について も TOC 值と相関が指摘されている ${ }^{114)}$.

またLC/MSにおいても TOCの低減の差が空試験のバッ クグラウンド, 分析感度に影響を与えることが報告されて いる ${ }^{15)}$.

微量（分析）試験に用いる水はJIS K 0557 用水・排水の 試験に用いる水において水質の種別を $\mathrm{A} 4$ と規定している.
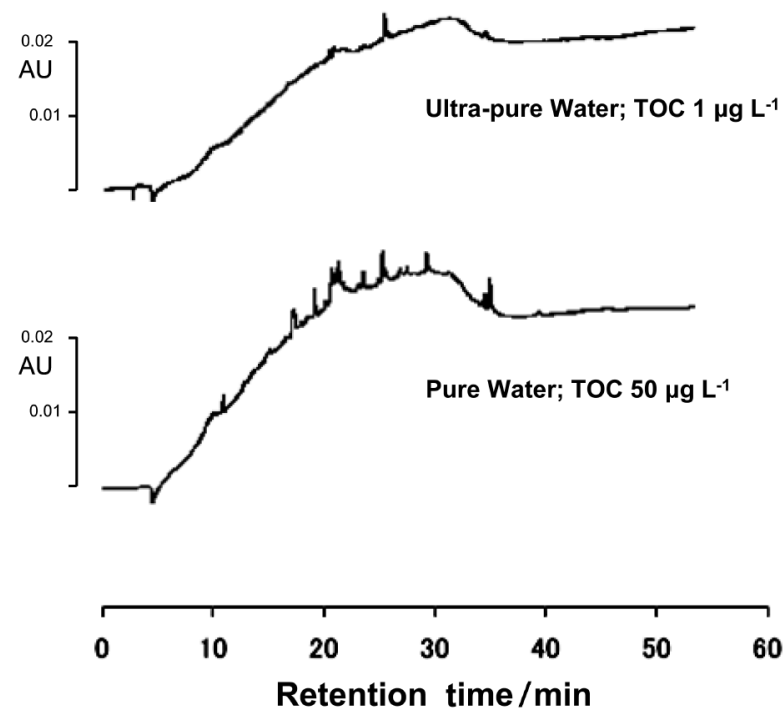

Fig. 3 Contamination peak of HPLC from pure water $^{12)}$

Table 4 Comparison of TOC by ultra-pure water systems

\begin{tabular}{lcccc}
\hline \multirow{2}{*}{ Water quality } & \multicolumn{4}{c}{ Purifications of ultra-pure water system } \\
\cline { 2 - 5 } & $\mathrm{IE}+\mathrm{AC}+\mathrm{MF}$ & $\mathrm{IE}+\mathrm{AC}+\mathrm{UF}$ & $\mathrm{IE}+\mathrm{AC}+254 \mathrm{UV}$ & $\mathrm{IE}+\mathrm{AC}+185 \mathrm{UV}$ \\
\hline Electric-resistivity $/ \mathrm{M} \Omega \mathrm{cm}$ & 18.2 & 18.2 & 18.2 & 18.2 \\
$\mathrm{TOC} / \mu \mathrm{gC} \mathrm{L}^{-1}$ & 5.4 & 5.4 & 3.1 & 1.4 \\
\hline
\end{tabular}


Table 5 JIS K 0557-1998. Water quality

\begin{tabular}{lcccc}
\hline \multicolumn{1}{c}{ Measurement materials } & \multicolumn{3}{c}{ Water quality } \\
\cline { 2 - 5 } & $\mathrm{A} 1$ & $\mathrm{~A} 2$ & $\mathrm{~A} 3$ & $\mathrm{~A} 4$ \\
\hline Electric-conductivity $\left(\mathrm{mS} \mathrm{m}^{-1}\right.$ at $\left.25^{\circ} \mathrm{C}\right)$ & $<0.5$ & $<0.1$ & $<0.1$ & $<0.1$ \\
Total Organic Carbon $/ \mathrm{mgC} \mathrm{L}^{-1}$ & $<1$ & $<0.5$ & $<0.2$ & $<0.05$ \\
$\mathrm{Zn} / \mu \mathrm{g} \mathrm{L}^{-1}$ & $<0.5$ & $<0.5$ & $<0.1$ & $<0.1$ \\
$\mathrm{SiO}_{2} / \mu \mathrm{g} \mathrm{L}^{-1}$ & - & $<50$ & $<5.0$ & $<2.5$ \\
$\mathrm{Cl}^{-} / \mu \mathrm{g} \mathrm{L}^{-1}$ & $<10$ & $<2$ & $<1$ & $<1$ \\
$\mathrm{SO}_{4}{ }^{2-} / \mu \mathrm{g} \mathrm{L}^{-1}$ & $<10$ & $<2$ & $<1$ & $<1$ \\
\hline
\end{tabular}

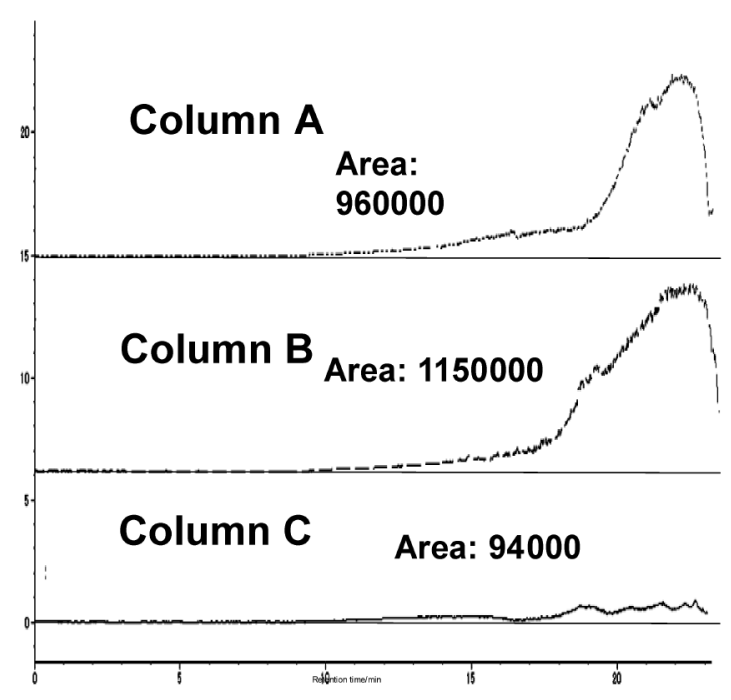

Column size: $2.0 \times 150 \mathrm{~mm}$ Mobile phase:

A) $0.1 \%$ acetic acid

B) $\mathrm{CH}_{3} \mathrm{CN}$

Gradient:

Time: $0 \mathrm{~min} 3 \mathrm{~min} 14.4 \mathrm{~min} 18 \mathrm{~min} 19 \mathrm{~min}$

\%B: $5 \% \quad 5 \% \quad 100 \% \quad 100 \% \quad 5 \%$

Flow rate: $0.2 \mathrm{~mL} \mathrm{~min}^{-1}$

Temperature: $40^{\circ} \mathrm{C}$

Detection: Corona CAD

Fig. 4 Comparison of extraction from HPLC C-18 column $^{17)}$

一般的にはこの A4 超純水の基準として扱うことが多い. $\mathrm{A} 4$ では TOC を $50 \mu \mathrm{gC} \mathrm{L}{ }^{-1}(50 \mathrm{ppb})$ 未満であることとし ている ${ }^{16)}($ Table 5). しかし Fig. 3 からも分かるように, HPLCで高感度分析を行うのであればJIS の A4を満たして いることでは不十分である。空試験もしくはサンプル調製 用水として用いた場合に実際の分析に影響を与えない水質 かどうかあらかじめ試験しておく必要があることが分か る.

3 微量分析における様々な污染要因

超純水は別名“ハングリーウォーター”とも呼ばれ, 物 質を非常に良く溶解する。 このことは超純水が非常に污染
されやすいことを示唆している. そのため, 微量分析に問 題が生じたときには水の污染が要因となることも多く, 結 果として超純水装置の不具合を疑うことも多い. しかし以 下に記述するように超純水装置そのものが問題である事例 は少ない. 但し装置の管理方法, 使用方法には問題が多い ことは指摘されている

実際の超純水の污染は環境からの要因がほとんどであ る. 主な要因として室内環境, 使用する容器, 実験者から の污染が挙げられる。これらの中には適切な実験操作によ り防止できるものもある.

\section{$3 \cdot 1$ 装置に起因する污染}

分析装置や超純水装置は超純水の污染源となり得る. 分 析や不純物除去の工程では装置の流路が超純水に曝される ため, 配管などからの溶出による污染が生じるからであ る.

$\mathbf{3} \cdot \mathbf{1} \cdot \mathbf{1}$ 分析装置内での污染 HPLC 分析に与える污 染例として分析用のカラムからの溶出があげられる. 長江 は一例として Fig. 4 に示すようにC18カラムからの溶出を 指摘している ${ }^{17)}$.

分析対象に応じたカラムの選定及び十分な洗浄が求めら れる。

また配管からの污染例もある。配管にテフロン系の素材 を用いている LC/MSからパーフルオロオクタン酸 （PFOA）が検出され, 問題となったことがある. 分析対象 物質の多様化で分析装置もその対応は容易ではないが, 分 析者も使用する分析装置そのものが分析対象物の分析に影 響を与える物質の溶出の恐れがないのか確認し，要因を除 去もしくは低減する必要があることを認識しなければなら ない.

3・1・2 超純水装置内での污染 $\quad \mathrm{LC} / \mathrm{MS}$ と同様に超純 水装置でも配管にテフロン系の素材を用いている機種から のPFOAの污染が疑われたことがある．配管にテフロン系

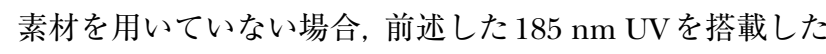
超純水装置 PURELAB Ultra Analytic（ELGA LabWater 製） で水質モニターにて TOC が 1 ppb の指示值を示した後に 採水した超純水中の PFOA, PFOS はそれぞれ $1 \mathrm{ng} \mathrm{L}^{-1}$ の 


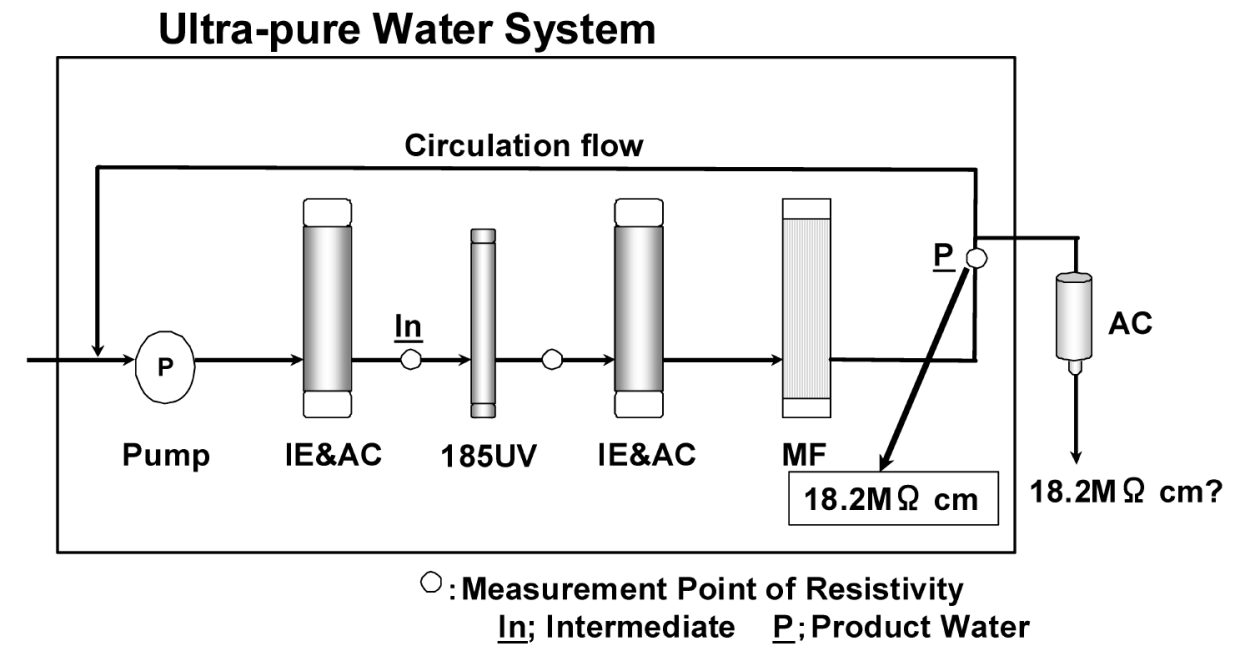

Fig. 5 Ultra-pure water system's flow

Table 6 Impurity levels in purified water of different resistivity

\begin{tabular}{lcccc}
\hline \multirow{2}{*}{ Impurity } & \multicolumn{4}{c}{ Concentrations $\left(\mu \mathrm{g} \mathrm{L}^{-1}\right)$ which could be present at resistivity of } \\
\cline { 2 - 5 } & $18.2 \mathrm{M} \Omega \mathrm{cm}$ & $18.0 \mathrm{M} \Omega \mathrm{cm}$ & $17.5 \mathrm{M} \Omega \mathrm{cm}$ & $15.0 \mathrm{M} \Omega \mathrm{cm}$ \\
\hline $\mathrm{Na}^{+}$ & 0.8 & 1.3 & 1.8 & 3.6 \\
$\mathrm{CI}^{-}$ & $<0.1$ & 0.2 & 0.5 & 2.1 \\
$\mathrm{Fe}^{2+}$ & 2.0 & 2.4 & 3.0 & 5.4 \\
$\mathrm{Na}^{+}+\mathrm{CI}^{-}+\mathrm{SO}_{4}{ }^{2-}$ & $<0.1$ & 0.3 & 1.1 & 5.4 \\
$\mathrm{NaCl}$ & $<0.1$ & 0.2 & 0.9 & 5.0 \\
\hline
\end{tabular}

検出限界未満であり污染は認められない ${ }^{11)}$. しかし常に超 純水装置からの溶出と水質の維持管理に留意しておかなけ れば分析対象物の分析に影響を与える可能性は十分にあ る.

また超純水の TOC が 1 ppb 未満に低減できない理由の ひとつは，イオン交換樹脂を大量に用いていることと配管 などの接液部にポリエチレンやポリプロピレンなどの樹脂 を用いていることにある。またラボで用いる超純水装置は 断続的に使用する場合がほとんどであり, 配管口径が小さ いため単位体積当りの配管への接液面積が大きく, 溶出が 起き易い ${ }^{3)}$. それでも系内の定期循環機能の採用などで高 水質を維持している. 配管からの污染が懸念されるフタル 酸エステル類やビスフェノールAなどの污染も見られな $\left(^{1) 18)}\right.$. しかし超純水装置の最終カートリッジを装置外に 設置した場合はFig. 5 で示されるように循環ラインから外 れるため, カートリッジからの溶出が起き, 水質低下を起 こす可能性がある。これを防ぐために最終カートリッジを 超純水の循環フロー内に装着するか, 採水時に初流を排水 することで水質劣化水の使用を防ぐ必要がある. 初流排水 を行う場合は陰イオンのppbオーダー未満までの低減であ れば $500 \mathrm{~mL}$ 程度の排水, HPLCのバックグラウンドの安 定であれば $1 \mathrm{~L}$ 程度の排水が必要であることが報告されて
いる ${ }^{1)}$.

$3 \cdot 1 \cdot 3$ 超純水装置の水質モニタリングの限界 超純 水装置から得られる水の水質は装置に装備されている水質 計を用いて測定されるが, その数值だけに頼ったモニタリ ングでは分析に影響を与えることがある.

超純水装置では水中の残存イオンの総量を電気抵抗值で モニタリングしており, 一般に $18.0 \mathrm{M} \Omega \mathrm{cm}$ 以上を超純水 と呼ぶ. 通常, 超純水装置から得られる超純水は $18.2 \mathrm{M} \Omega$ $\mathrm{cm}$ 以上で, 理論純水の抵抗值である $18.25 \mathrm{M} \Omega \mathrm{cm}$ にほほ 到達している。この值を示している超純水中に不純物のイ オンはほとんど存在しない（Table 3). しかし Table 6で 示すように比抵抗計が $18.2 \mathrm{M} \Omega \mathrm{cm}$ を示していても数 100 ppt 程度のイオンが存在している場合がある ${ }^{1)} .18 .0 \mathrm{M} \Omega$ $\mathrm{cm}$ ではppbレベルのイオンの存在が認められる.

特にホウ素, シリカは, イオン交換樹脂の特性上比抵抗 值が $18.2 \mathrm{M} \Omega \mathrm{cm}$ 以上を示していても Fig. 6 に示すように ppb レベルのリークが始まることが知られており実際に報 告されている ${ }^{19)}$.

ICP-MS やイオンクロマトを用いて微量成分を ppt ある いはppq レベルまで分析する場合は, 製造水の比抵抗の変 化に十分留意し, 必要であれば変化が生じる前にイオン交 換樹脂を交換する必要がある. そのためには Fig. 5 で示す 
超純水装置のように装置内に複数のイオン交換カートリッ ジを配置し，その中間において比抵抗值をモニタリングし てイオン交換樹脂の交換指標とすることが有効である.

Fig. 7 で示すように中間水質が低下した後でイオン交換カ ートリッジを交換しても実際の製造水質は比抵抗 $18.2 \mathrm{M} \Omega$ $\mathrm{cm}$ を維持することが出来る. 但しこの場合であってもホ ウ素のリークのタイミングを比抵抗值によって明示するこ とは難しいため, カートリッジの早期交換が求められる.

\section{$3 \cdot 2$ 環境からの污染}

$3 \cdot 2 \cdot 1$ 雰囲気からの污染 超純水を大気開放中に放 置すれば 1 時間もすれば $0.1 \mathrm{ppb}$ 程度の陰イオンが検出さ

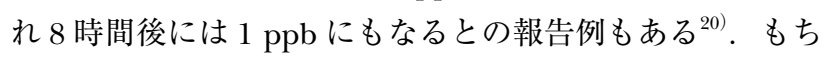
ろん室内環境の違いによりその濃度にも差が現れてい $る^{1)}$. 密封容器上部の空気ですら污染されているとの報告 もある ${ }^{20)}$. 超純水は出来るだけ採水直後に使用することを こころがけ，保管はしないことが望ましい，やむを得ず保 管が必要な場合には䨌囲気からの污染を排除するために容 器内を超純水で満たし密封しておく.

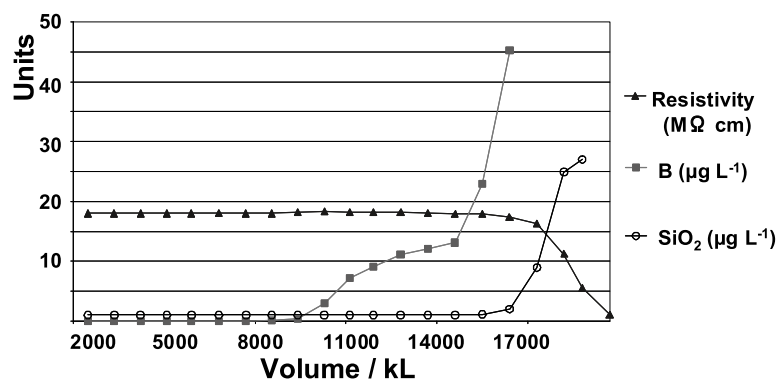

Fig. 6 Lifetime of ion exchange resin in ultra-pure water system for $\mathrm{B}$ or $\mathrm{SiO}_{2}$ analyses ${ }^{19)}$
$3 \cdot 2 \cdot 2$ 容器からの污染超純水を装置から採水する 場合も分析装置へ試料を導入する場合も容器が必要とな る. 先にも述べたように超純水は非常に溶解力が高いため 容器に付着した污れだけでなく容器そのものを溶かし込 む. そのため容器の選定と容器の洗浄が重要になる.

例えば有機物分析であればガラス容器が最適 ${ }^{1}$, イオン 分析であればポリプロピレン容器が最適 ${ }^{20)}$ るいはポリエ チレン容器 ${ }^{1)}$ が良いとの報告もある。この例では実際にガ ラス容器からは 1 ppbを超える塩化物イオンの検出が見ら れたがポリプロピレンやポリエチレン容器からは $10 \mathrm{ppt}$ 未 満に抑えられている.

分析機器メーカーによっては専用容器を推奨している. LC/MS 専用のバイアルでの比較では明らかにバックグラ ウンドに差が見られる ${ }^{21)}$.

$\mathbf{3} \cdot \mathbf{2} \cdot \mathbf{3}$ 容器の洗浄の影響 また容器の洗浄も污染を 左右するとの報告がある. Fig. 8 は洗浄後クリーンな環境に て乾燥保管していたガラス製三角フラスコを用いて LC/MS

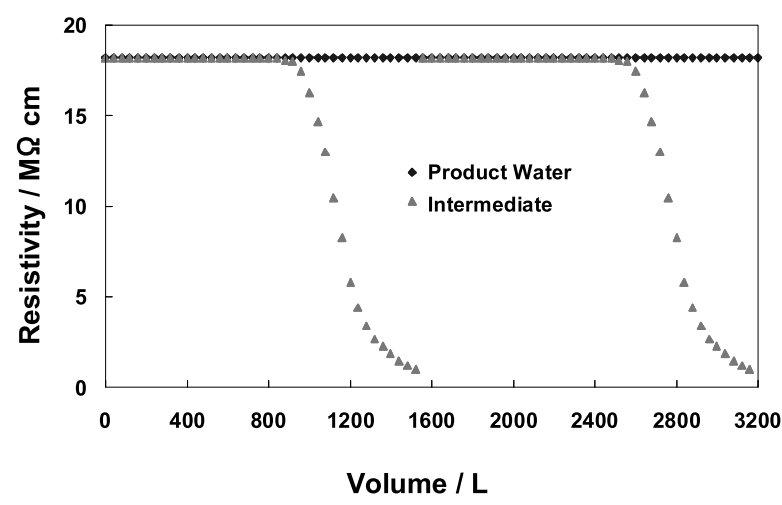

Fig. 7 Lifetime of ion exchange resin in ultra-pure water system
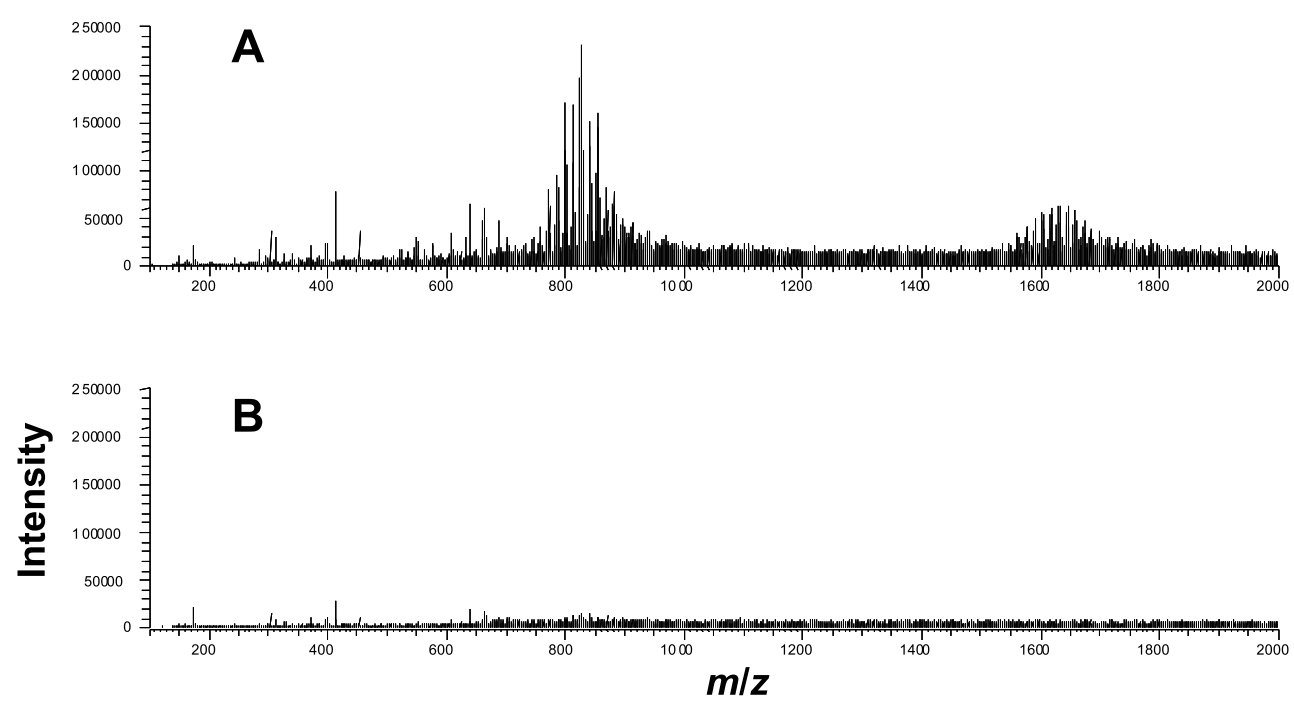

Fig. 8 Organic matters contamination from conical flask ${ }^{22)}$ 


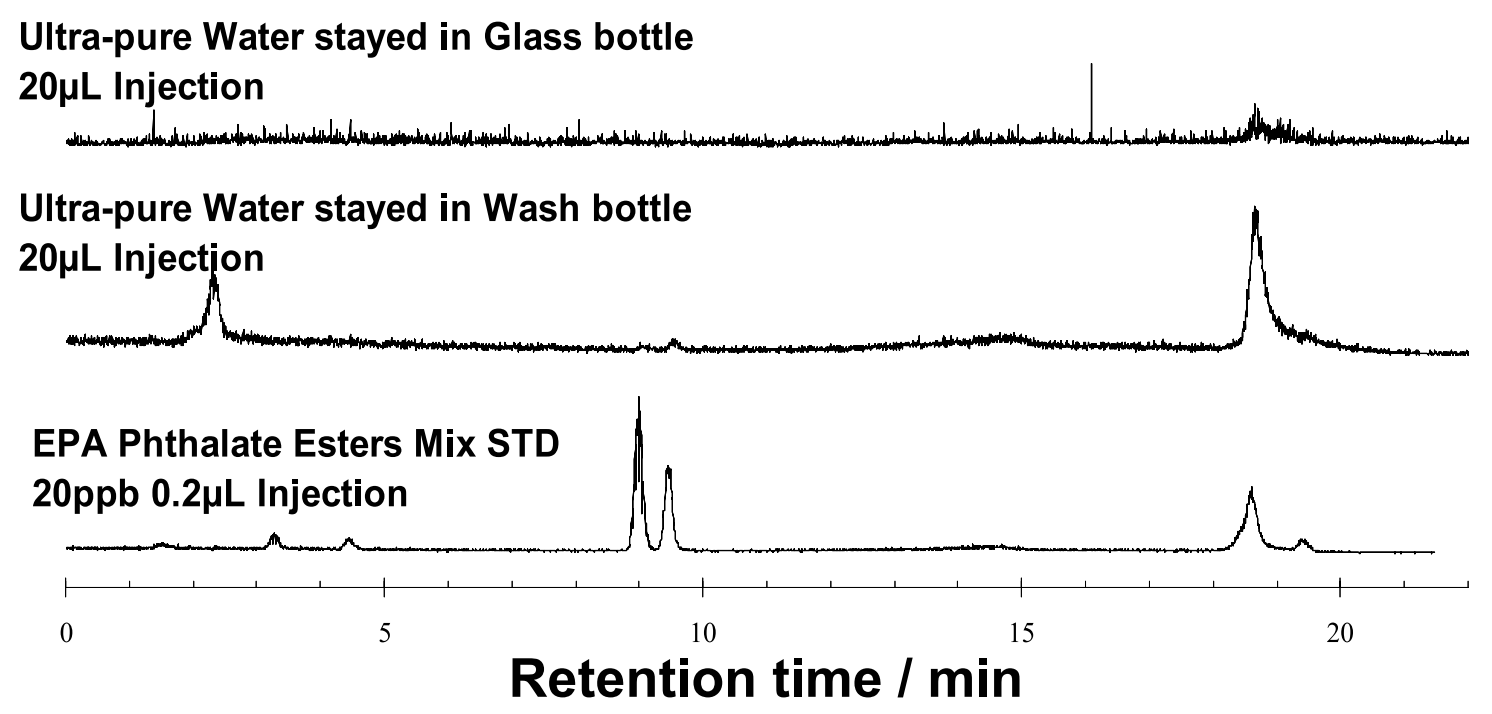

Fig. 9 Phthalates contamination from wash bottle ${ }^{26)}$

分析を行った際にそのフラスコをとも洗いを行った場合と 行わなかった場合の比較である．A はとも洗いをせずにそ のまま移動相に用いるアセトニトリルを採取し分析に供し た. B は移動相に用いるアセトニトリルを 3 回とも洗いした 後に採取し分析に供した. 溶媒のとも洗いの有無で LC/MS のバックグラウンドに大きな差が出ている ${ }^{22)}$. また $m / z$ が 14 間隔でピークが認められ界面活性剤の残存が示唆され た.

半導体分野では超純水の試験方法が JIS K 0551 超純水中 の有機体炭素（TOC）試験方法, JIS K 0553 超純水中の金 属元素試験方法, JIS K 0556 超純水中の陰イオン試験方法 などとして JIS 化されており，その洗浄法を採用するのも 有効な選択肢となるであろう。これらの JIS 試験法には試 料容器の洗浄の項を設けて規定している. 硝酸及び超純水 による複数回の洗浄を行うこととされているが, 洗浄後容 器内に超純水を封入して 16 時間放置後廃棄し, その後で

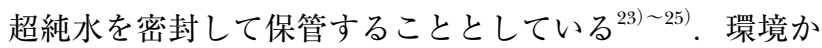
らの污染を避ける有効な手段である. 使用時には当然超純 水でのリンスと, とも洗いが必要である.

$\mathbf{3} \cdot \mathbf{2} \cdot \mathbf{4}$ 洗ビンからの污染 洗ビンは実験や洗浄に広 く用いられているが，その使用方法や管理は十分とはいえ ない. 著者が 2005 年に主に環境分析の HPLCを用いる分 析者にアンケートを実施した結果では，約 $10 \%$ しか使用 前に洗ビンの水を入れ替えておらず，更に $10 \%$ 程度が毎 日洗ビンの水を交換していると回答した。つまり $80 \%$ の 分析者は新鮮な超純水を用いていないとの結果であった. そこで一般的な使用例として想定できる 2 日間実験室で普 段通りに使用した洗ビンの超純水と, 2 日間ガラスビンに 封入した超純水を LC/MS で比較した. 分析対象としてフ タル酸エステル類を選定した. Fig. 9 に得られたトータル イオンクロマトグラフ (TIC) を示す. 1 番目がガラス瓶に
超純水を 2 日間保管した水，2番目が超純水を入れ 2 日間 使用した洗ビン中の水, 一番下はフタル酸エステル 6 種の 混合標準液をインジェクションしたものである. 洗ビン中 の超純水からは明らかに ppbレベルの Di- $n$-octyl phthalate が検出された ${ }^{26) 27)}$.

通常であればそのまま用いても問題とならない分析や実 験もあるであろう。しかし微量分析を行う場合に直前に洗 ビンの超純水を入れ替えてできるだけ新鮮な超純水を使用 することで分析用水の污染要因をひとつ減らすことが出来 る.これは購入して用いるボトル水の使用において, 開封 後の保管や再使用についても同様にあてはまる問題であ る. 開封した分析用水の再使用は分析の精度に大きな影響 を与えることを留意しなければならない. ボトル水は 200 $\mathrm{mL}$ 以下の低容量のタイプも販売されているので, 開封後 はその都度使い切ることをこころがけて, 再使用はできる だけ避けるべきである.

\section{$3 \cdot 3$ 実験操作}

$3 \cdot 3 \cdot 1$ 採水時の雰囲気からの污染 超純水装置から 超純水を採水する場合の雾囲気からの污染例を示す.

䨌囲気からの污染をイオンクロマトグラフィーによる陰 イオン分析で比較した（Fig. 10). クロマトグラムを重ね て表示しているが，下のクロマトは特に注意せずに泡立た せて採水した場合で，㓌イオンを高い濃度で検出した．特 に高いピークは亜硝酸イオンであった ${ }^{12)}$ ．採水時に環境か ら巻き込んだものと考えられる。超純水装置から超純水を 容器に受ける際に普通に泡立てながら採水しただけでも水 質は変化する ${ }^{1)}$. 超純水装置から超純水を採水する場合に は，流量をコントロールしてできるだけ泡立てず，空気を 混入させないことが重要である.

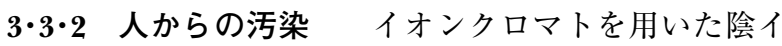




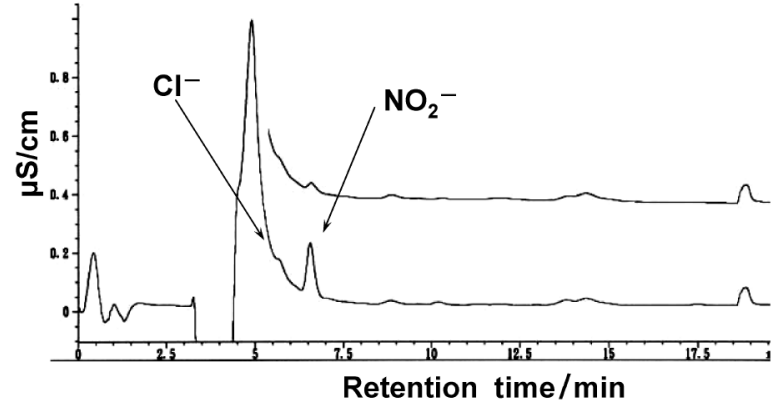

Fig. 10 Anion contamination from atmosphere ${ }^{12)}$

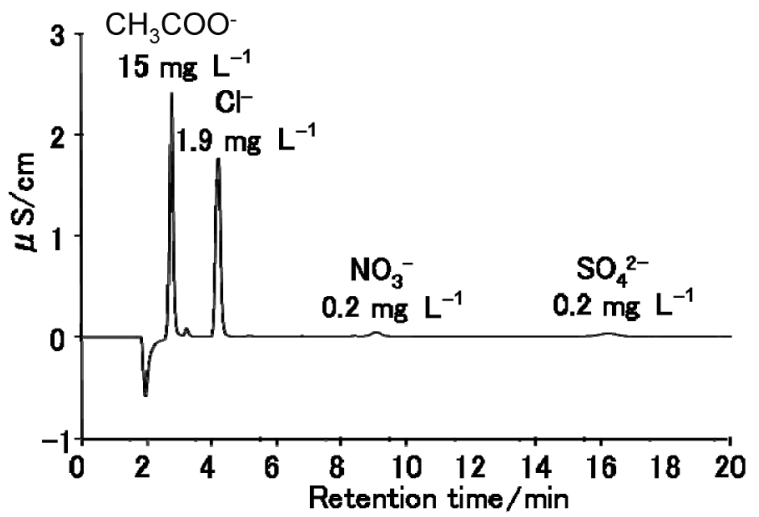

Fig. 11 Anion contamination from human finger ${ }^{28)}$

オン分析で，超純水の採水中に水に指が触れてしまった が，そのまま分析した事例がある ${ }^{28)}$. Fig. 11 に示すように 酢酸イオンが $15 \mathrm{mg} / \mathrm{L}$ ，塩化物イオンが $2 \mathrm{mg} / \mathrm{L}$ 検出され ている．採水時に限らず操作中超純水の污染が起きる可能 性は高い。注意するとともに，污染の可能性があれば廃棄 しなければならない。

污染要因は分析の操作に数多く潜んでおり, 管理, 注意 を怠ると分析の精度に大きな影響を与えかねないことを十 分留意する必要がある。

$$
4 \text { ま め }
$$

本稿は微量分析に影響を与えた事例を羅列したに過ぎな いし，超純水そのものが起因あるいは関係していないもの も含まれている．しかし超純水及び超純水装置への適切な 理解と取り扱いで分析の信頼性を向上させることが出来る ことが分かる.

\section{謝辞}

本稿をまとめるにあたり，貴重なご助言とデータをご提 供いただきました関東化学(侏澤田豊氏，日本ダイオネクス
(株)鈴木隆弘氏，(株)クロマニックテクノロジーズ長江徳和 氏, セントラル科学(株松永広助氏，そして HPLC 研究懇談 会運営委員及びオルガノ株の諸氏に感謝いたします。また 多くの事例をお寄せいただいた数多くの分析化学者の方々 にお礼申し上げます。

\section{文献}

1) 黒木祥文: 工業用水, 541, 24 (2003).

2) 熊井広哉, 石井直恵, 金沢旬宣, 黒木祥文: “超純 水超入門”改訂版, (2003), (日本ミリポア).

3) 黒木祥文: 配管と装置, 1998, 37.

4) 黒木祥文：クリーンテクノロジー, 2002-12, 19.

5) A. Sabarudin, M. Oshima, N. Ishii, S. Motomizu : Talanta, 60, 1277 (2003)

6) 李 貞海, 大島光子, 本水昌二：分析化学 (Bunseki Kagaku), 53, 345 (2004).

7) 黒木祥文: クリーンテクノロジー, 1996-6, 19.

8) 黒木祥文: 用水と廃水, 41, 70 (1998).

9) 黒木祥文, 石井直恵, 臼井 淳: 第 8 回環境化学 討論会講演要旨集, p. 92 (1999).

10) 石井直恵, 黑木祥文, 関 好恵, 松村 徹：第 9 回環境化学討論会講演要旨集, p. 92 (2000).

11）島田哲治，川口 修，岩森智之，黒木祥文：第 16 回環境化学討論会講演要旨集, p. 92 (2007).

12) 黒木祥文: Chromatography, 27, 125 (2006).

13) オルガノ株式会社: “超純水 (Chojunsui)”, オルガ ノ超純水製作委員会編, p. 390 (1991), (オルガノ).

14) HPLC 研究懇談会運営委員会：“液ク口 龍の巻”, 中村 洋編, p. 70 (2003), (筑波出版会)

15) HPLC 研究懇談会運営委員会: “液ク口 龍の巻”, 中村 洋編, p. 137 (2003), (筑波出版会).

16) JIS K 0557, 用水・排水の試験に用いる水 (1998).

17) クロマニックテクノロジーズ：日本薬学会第 129 年会新技術セミナー発表スライド, available from <http://www.chromanik.co.jp/2009yakugaku. html >, (accessed 2009-11-02).

18）黑木祥文：環境浄化技術，2003-2, 71.

19) S. Malhotra, O. Chan, T. Chu, A. Fusko: Ultrapure Water, 13, 22 (1996).

20) 酒井徹志, 小野雅章, 井上嘉則 : 工業用水, 458 , 43 (1996)

21) 日本ウォーターズ：“LC/MS 品質保証バイアル”, available from <http://www.waters.com/waters/ nav.htm? cid $=10091784 \&$ locale $=145>, \quad$ (accessed 2009-11-02).

22) HPLC 研究懇談会運営委員会：“液クロ 武の巻 (Ekikuro Bu No Maki)”, 中村 洋編, p. 112 (2003), (筑波出版会).

23）JIS K 0553，超純水の金属元素試験方法 (2003).

24）JIS K 0556，超純水の陰イオン試験方法 (1995).

25）JIS K 0551，超純水の TOC 試験方法 (1994).

26) 鈴木菜穂子, 川口 修, 榎並敏行, 黒木祥文：第 15 回環境化学討論会講演要旨集, p. 182 (2006).

27) 堀切 智, 藤田直樹, 小林英樹, 黒木祥文, 榎並敏 行: 第 54 回質量分析総合討論会講演要旨集, p 458 (2006)

28) 黒木祥文：第 24 回イオンクロマトグラフィー討論 会要旨, p. 106 (2007). 


\title{
Influence of Impurities in Ultra-Pure Water on Ultratrace Analyses with Analytical Instruments
}

\author{
Yoshifumi KuROKI ${ }^{1}$
}

\begin{abstract}
${ }^{1}$ Veolia Water Solutions \& Technologies Japan K.K ELGA LabWater Global Operations, Yokoso Rainbow Tower, 3-20-20, Kaigan, Minato-ku, Tokyo 108-0022
\end{abstract}

(Received 30 November 2009, Accepted 6 January 2010)

\begin{abstract}
The quality of water has a significant influence on instrumental analyses. In the microanalysis of trace elements or organisms by ICPMS, ion chromatography, HPLC or LC/MS, remaining materials in the blank water should be decreased to less than ppt. Today we can easily obtain ultra-pure water of such a high quality for analytical instruments using a high-performance water purifier. However, we often make mistakes in the usage of ultra-pure water, and also in the operation of a water purifier. The manner to use ultra-pure water is quite important, as well as the performance of the water purifier. It is necessary to make a standard method to use ultrapure water for trace elements or organisms analysis.
\end{abstract}

Keywords : ultra-pure water ; ultramicro analysis ; impurity ; contamination ; trace organisms. 